\title{
The possibilities and pitfalls presented by a pragmatic approach to ecosystem service valuation in an arid biodiversity hotspot
}

\author{
P.J. O'Farrell ${ }^{\mathrm{a}, *}$, W.J. De Lange ${ }^{\mathrm{a}}$, D.C. Le Maitre ${ }^{\mathrm{a}}$, B. Reyers ${ }^{\mathrm{a}}$, J.N. Blignaut ${ }^{\mathrm{b}}$, S.J. Milton ${ }^{\mathrm{c}}$, D. Atkinson ${ }^{\mathrm{d}}$, \\ B. Egoh ${ }^{\mathrm{e}}$, A. Maherry ${ }^{\mathrm{a}}$, C. Colvin ${ }^{\mathrm{a}}$, R.M. Cowling ${ }^{\mathrm{f}}$ \\ a Natural Resources and the Environment, CSIR, P.O. Box 320, Stellenbosch 7599, South Africa \\ ${ }^{\mathrm{b}}$ Department of Economics, University of Pretoria, ASSET Research, and Jabenzi, Pretoria 0001, South Africa \\ 'School of Natural Resource Management, Nelson Mandela Metropolitan University Saasveld Campus, Saasveld street, George 6529, South Africa \\ ${ }^{\mathrm{d}}$ Research Cluster on Sustainable Development and Poverty Reduction, University of the Free State, PO Box 139, Philippolis 9970, South Africa \\ e Department of Plant Science, University of Pretoria, Botany Building, room 1-6, Lynwood Road, Pretoria 0002, South Africa \\ ${ }^{\mathrm{f}}$ Department of Botany, Nelson Mandela Metropolitan University, P.O. Box 77000, Port Elizabeth 6031, South Africa
}

\section{A R T I C L E I N F O}

\section{Article history:}

Received 15 June 2010

Received in revised form

21 October 2010

Accepted 11 January 2011

Available online xxx

\section{Keywords:}

Conservation

Human wellbeing

Resource limited

Scarcity of services

Sustainable land-use

\begin{abstract}
A B S T R A C T
Arid regions are home to unique fauna, flora, and vulnerable human populations, and present a challenge for sustainable land-use management. We undertook an assessment and valuation of three key services, grazing, tourism and water supply in the arid Succulent Karoo biome in western South Africa - a globally recognised biodiversity hotspot. We were looking for ways and values that could be used to promote conservation in this region through the adoption of sustainable land-use practices which have human welfare benefits. Our study adopted a variety of methods in valuing these services in developing ranges of values for these services. At the biome level, total annual values ranged from \$19-114 million for grazing, \$2-\$20 million for tourism, and \$300-3120 million for water. These values are generally low compared with values derived for other biomes and regions and do not adequately reflect known dependence and the importance of ecosystem services to the residents of this biome. The ecosystems here provide small but critical benefits enabling communities to sustain themselves and small changes in service levels can have major welfare effects. Highlighting these sensitivities will require finding more appropriate ways to link ecological and social factors.
\end{abstract}

() 2011 Elsevier Ltd. All rights reserved.

\section{Introduction}

Ecosystem service assessment has become an important tool in the development of sustainable land-use practices and natural resource management with an increasing number of decision makers requesting such assessments. Valuation has developed as one of the cornerstones of this rapidly growing research area. The ability to summarise and express complex ecological interactions in a single common currency is very appealing. This enables the explicit evaluation of tradeoffs between different services and between services and other forms of capital (e.g. manufactured capital), and greater ease in communicating the importance of ecosystem services to policy makers (Heal, 2000; Ludwig, 2000; Farley and Brown Gaddis, 2007; TEEB, 2008; Ash et al., 2009; Tallis and Polasky, 2009). Economic valuation has been used to add to conservation efforts, to reinforce scientific and ethical

\footnotetext{
* Corresponding author. Tel.: +27 21888 2476; fax: +21 866196737 .

E-mail address: pofarrell@csir.co.za (P.J. O’Farrell).
}

reasoning (Balmford et al., 2002; Turner et al., 2010), to make explicit the link with human wellbeing and development and to explore the potential for incentives like payments for ecosystem services (PES) (Wunder, 2005; Cowling et al., 2008; Ash et al., 2009; Daily et al., 2009; Wendland et al., 2009).

The valuation of ecosystems and their services is supported by a growing body of literature on conceptual approaches, technical valuation methods and operational issues (Simpson, 1998; Turner et al., 1998, 2010; Costanza, 2003). Despite these advances ecosystems remain difficult to value given their complex behaviour, nonlinear responses and their potential to undergo irreversible change (Chavas, 2000; Ludwig, 2000; Norgaard et al., 2007). The services they produce are also multiple and interdependent, and differ in terms of their ease of valuation (Turner et al., 2003), leading to a risk of excluding or undervaluing key ecosystem services (Redford and Adams, 2009). Added to these concerns, and of central interest here, is the influence that the type and location of beneficiaries will have on the value calculated. The values people place on ecosystem services are considered to be highly dependent on social and 
environmental factors (Carpenter and Folke, 2006). Valuation therefore requires an understanding of the spatial scales at which services are generated and flow, where benefits are realised and to which beneficiaries, to which components of their wellbeing, and taking into account the beliefs and value systems of the owners, managers and beneficiaries of ecosystem services (Turner et al., 2003; Hein et al., 2006; Wilson et al., 2006; Brauman et al., 2007; Chan et al., 2007; Norgaard et al., 2007; Tallis and Polasky, 2009).

Whilst research and development in the field of ecosystem services has increased dramatically (Egoh et al., 2007; Daily and Matson, 2008; Fisher and Turner, 2008; Daily et al., 2009), the focus of these studies has not been evenly distributed across the world's different habitats and regions. Mesic biomes such as tropical forests and estuaries, and tropical biodiversity hotspots have received a disproportionally large amount of attention (Fisher et al., 2008). Arid and semi-arid regions, typically those areas viewed as marginal in terms of biological productivity and ecosystem service values (Costanza et al., 2007; Naidoo and Iwamura, 2007), with low human population levels, have received less. This is unsurprising given that ecosystem service research has emerged partly in response to the conservation crisis (Balmford and Cowling, 2006), with a focus on tropical hotspots and areas of large biodiversity losses which are seldom congruent with arid environments (Mittermeier et al., 2005). The focus has also been on areas with existing data and knowledge (e.g. Wisconsin (e.g. Nelson et al., 2009) or California (e.g. Chan et al., 2006)) which have rarely included arid regions. Furthermore, global studies which have incorporated arid regions into their analysis (Costanza et al., 1997; Sutton and Costanza, 2002), have found these to be areas with a scarcity of services with some of the lowest associated ecosystem service values (Turner et al., 2007).

However, some arid areas are home to unique fauna and flora, as well as vulnerable human populations, which may benefit from an ecosystem services approach to sustainable land-use management (Safriel et al., 2005; Reyers et al., 2009; O'Farrell et al., 2010).This is the case in the arid Succulent Karoo biome in South Africa. The Succulent Karoo biome is a globally recognised biodiversity hotspot with highly endemic and threatened biodiversity facing increasing land-use pressures and climate change. The biodiversity of this region has received considerable research attention (Cowling et al., 1999a, 1999b; Cowling and Pierce, 1999). The area is also home to some of the most vulnerable people in South Africa with high unemployment and poverty levels (22-75\%) (CSIR 2007). Considering the significance and vulnerability of this area and the detailed level of biodiversity research already undertaken, the conservation community thought it worthwhile to explore the potential that ecosystem service assessment and valuation could provide in making a case for conservation, thereby complementing prior research activities. This could facilitate securing regional and national political support and resources for conservation, promoting sustainable land-use practices, possibly developing PES schemes, and raising awareness of the importance of ecosystem service and their linkages to human wellbeing in arid areas. Furthermore, as one of only two arid biodiversity hotspots in the world (Mittermeier et al., 2005) the Succulent Karoo also represents an extreme case of ecological and social vulnerability (Safriel et al., 2005; Fisher and Christopher, 2007; Hoffman and Rohde, 2007) and a unique opportunity to test some of the learning and approaches to assessing and valuing ecosystem services outside of temperate and tropical biomes. Finally it also provides an opportunity to test and possibly challenge Turner et al.'s (2007) claim that specialised conservation approaches beyond those offered by ecosystem services, are required for this arid region.

This study follows on from a biophysical assessment of the ecosystem services of the Succulent Karoo biome (see O'Farrell et al., 2010) and has as its objectives: the production of spatially explicit economic valuations of the biome; an improved understanding of the links between ecosystems, value, service scarcity, and human wellbeing in an arid context; an investigation of the potential of these valuations to promote conservation actions; and finally, to highlight some of the learning generated in undertaking this conservation sector requested assessment and to provide suggestions and direction for enhancing economic valuation within the context of ecosystem service assessment.

As is typical with many user demanded assessments of this nature, we were forced due to a lack of time, adequate data and funding to adopt a highly pragmatic approach to valuing ecosystem services. We blended economic valuation techniques with financial analysis techniques, used financial values as proxy values for ecosystem service values where applicable, and undertook multiple valuation approaches for single services. Using these approaches we generated potential ranges of ecosystem services values for selected services instead of trying to provide single best estimates. State of the art economic approaches focussed on generating consumer surplus-based marginal values, ecological production functions, models of future supply and demand and consumers willingness-to-pay, would take years and incredible funding to deliver narrower ranges and possibly more theoretically valid figures. Our aim therefore was not to come up with a single "right" value, but rather to foster understanding and awareness of arid systems and their ecosystem services.

\section{The Succulent Karoo biome}

The Succulent Karoo is an arid biome is situated in western Southern Africa, and covers $111,000 \mathrm{~km}^{2}$, and is the forth largest biome in Southern Africa (Mucina et al., 2006). It is the most diverse arid environment in the world having exceptionally high levels of biodiversity among plants, reptiles and invertebrates, birds and mammals (Cowling et al., 1999a; CEPF, 2003; Desmet, 2007; SKEP, 2008). The topography is flat and gently undulating, disrupted by hills in places. The biome can be divided into five broad physiographic regions with the northern region divided into coastal plains and mountains, the south central region divided into mountains and plains, hills and lowlands, and the eastern most region all being distinctly separate (Mucina and Rutherford, 2006). The altitude varies from sea level to $1500 \mathrm{~m}$, but most lies below $800 \mathrm{~m}$ (Mucina et al., 2006). Rainfall is regarded and highly predictable and mostly cyclonic falling during the winter months between April and September and varies between 100 and $300 \mathrm{~mm}$ per year, with and average of $170 \mathrm{~mm}$ (Mucina and Rutherford, 2006). This rainfall gradient increases from west to east and from north to south. Despite being one of the least economically developed and populated regions in South Africa with only 312,000 people (mean population density of 3.76 people $/ \mathrm{km}^{2}$ ), it is under pressure due to mining, irrigated cultivation in some areas, overstocking of livestock. Furthermore, projected climate change is arguably the greatest threat to this region (Hoffman and Ashwell, 2001; Hewitson and Crane, 2006; Keay-Bright and Boardman, 2006; Rouget et al., 2006; MacKellar et al., 2007; Thompson et al., 2009).Under conditions of climate change, rainfall in the western and northern regions are expected to experience the largest decreases in the biome (MacKellar et al., 2007). Extensive livestock farming is the primary land-use activity as irrigated agriculture is limited and confined to those regions with suitable soils and relatively reliable water supplies.

The above mentioned threats affect not only the ecological systems but also the social and economic systems of the region. It is home to some of the most vulnerable people in South Africa who depend directly on a variety of natural resources for much of their 
livelihoods and ultimate survival (James et al., 2005). The people of Nama origin who live on communal lands here are at the extreme of this dependency and are, therefore, very vulnerable to fluctuations in services. The percentage of the population below the mean living level, the minimum household income required to meet basic needs (Statistics South Africa, 2007), is about 27\%. The situation appears to be worsening as the labour dependent agricultural industry transitions to a more tertiary sector focus and the mining industry adopts labour reducing practices to remain globally competitive. As a result out-migration as well as social grant dependency is increasing in some parts of the region (CSIR 2007). This creates a unique suite of developmental challenges, requiring the adoption of more appropriate land-use strategies and alternative ways of living and sources of fulfilling livelihoods. One of these options in the region is tourism which is seen as a significant economic growth opportunity because it creates employment at a variety of skills levels as well as creating many business development opportunities such as accommodation, tour guiding, transport, marketing and crafts. Tourism in the biome has become a more dominant economic activity in recent times (Hoffman and Rohde, 2007) associated with spring flower displays, undeveloped landscapes and conservation areas (including transfrontier parks).

\section{Ecosystem service assessment}

As is often the case in conservation and ecosystem service assessments, ecological boundaries seldom overlap with administrative boundaries. In attempting to circumvent this issue which has become known as the modifiable areal unit problem (Jelinski and $\mathrm{Wu}$, 1996), we used the Succulent Karoo biome as defined by Mucina and Rutherford (2006), to identify the municipal districts within the Succulent Karoo, as well as the proportional contribution this biome makes to the area of each municipal district (Fig. 1). All socioeconomic data relevant to this study have been collected at the municipal district level. This aggregated data is fairly coarse and introduces issues of scale which are irresolvable in a study of this nature. A total of 21 districts containing varying areas of the Succulent Karoo biome formed the basis of this study, 10 of which include high priority conservation areas identified by SKEP (2003) (see Table 1).

Based on literature, stakeholder interviews and expert workshops we identified multiple beneficiary groups associated with a variety of services from the Succulent Karoo (see O'Farrell et al., 2010). These beneficiaries varied from local communities using natural vegetation for grazing and medicines, to researchers at Universities outside of the biome who study the unique flora of the region. Using a prioritisation system of importance to the vulnerable beneficiary groups, relevance to the region's socio-economic development and links to ecosystem integrity and therefore conservation, we focussed our ecosystem services valuation on the services associated with water, grazing and tourism (O'Farrell et al., 2010). The primary beneficiaries of these services were identified as farmers and farm workers for the grazing service; local town and settlement residents, their municipalities and industries for the water service; and both tourists (predominately urban dwellers outside of the region) and tourism operators and employees for the tourism service. A detailed biophysical analysis of these services is provided by O'Farrell et al. (2010).

In order to explore the links between ecosystems services, human wellbeing and the potential for using economic valuations to promote conservation actions we adopted a variety of practical approaches to the valuation of each service. We present a range of values (possible upper and lower values), and display the results in four different ways.

1. A total \$ value estimate for the Succulent Karoo according to each district

2. A $\$$ per $\mathrm{km}^{2}$ value for each district

3. A per capita $\$$ value for each district

4. A $\$$ value of the service proportional to the per capita gross value added (GVA). Per capita gross value added is equal to total

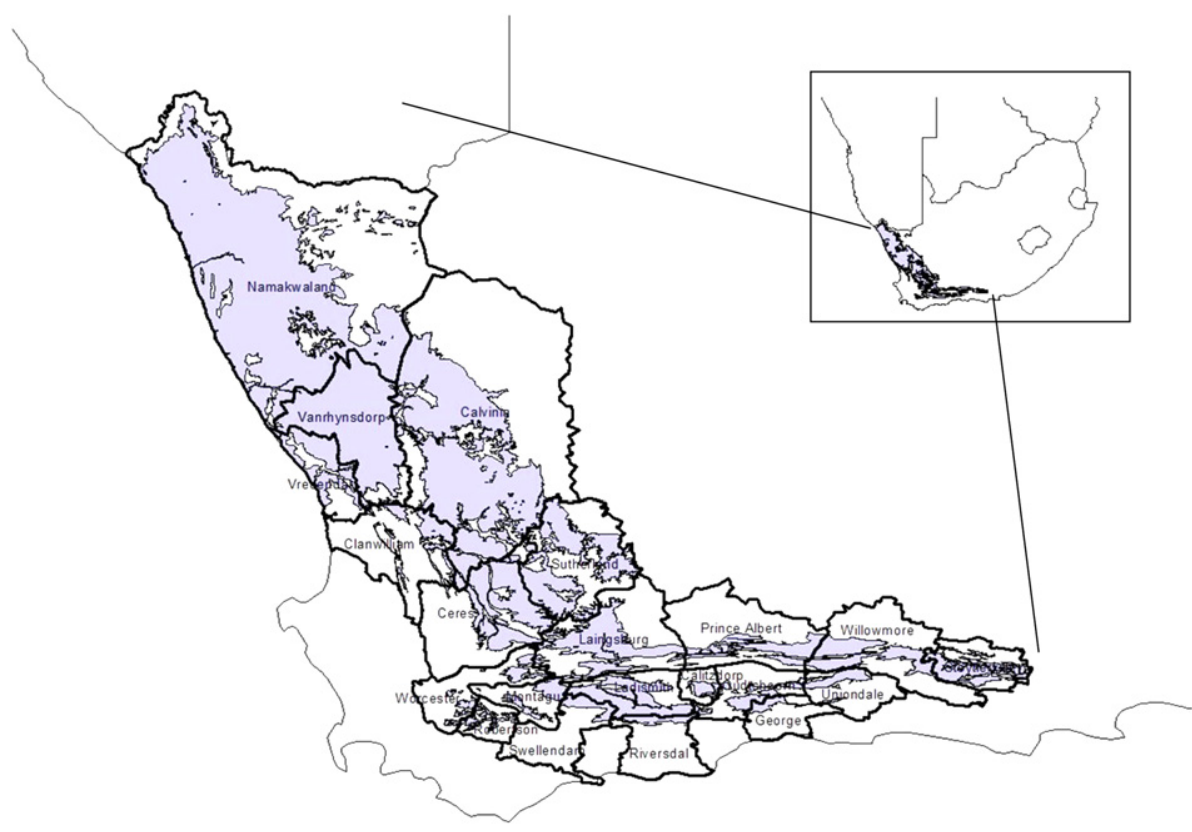

Districts

Succulent Karoo Biome

National Boundaries
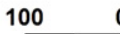

100

200 Kilometers

Fig. 1. Succulent Karoo biome with overlapping magisterial districts, and its location within southern Africa. 
Table 1

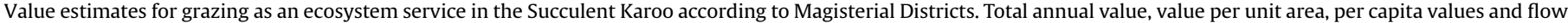
values estimated as a \% of GVA (Gross Value Added) per capita are presented. Highlighted districts are conservation priority areas.

\begin{tabular}{|c|c|c|c|c|c|c|c|c|c|c|c|c|}
\hline \multirow[t]{2}{*}{$\begin{array}{l}\text { Magisterial } \\
\text { District }\end{array}$} & \multicolumn{3}{|c|}{ Total annual value (\$) } & \multicolumn{3}{|c|}{$\begin{array}{l}\text { Total annual Value per unit area } \\
\left(\$ / \mathrm{km}^{2}\right)\end{array}$} & \multicolumn{3}{|c|}{ Per capita values (\$/capita) } & \multicolumn{3}{|c|}{$\begin{array}{l}\text { Flow value estimate (as \% of } \\
\text { GVA/cap) }\end{array}$} \\
\hline & Real & Sustainable & Substitution & Real & Sustainable & Substitution & Real & Sustainable & Substitution & Real & Sustainable & Substitution \\
\hline Calitzdorp & $\$ 365349$ & $\$ 256250$ & $\$ 722753$ & $\$ 1247$ & $\$ 875$ & $\$ 2467$ & $\$ 41$ & $\$ 29$ & $\$ 81$ & $1.3 \%$ & $0.9 \%$ & $2.6 \%$ \\
\hline Calvinia & $\$ 5319617$ & $\$ 3870461$ & $\$ 46044921$ & $\$ 331$ & $\$ 241$ & $\$ 2867$ & $\$ 250$ & $\$ 182$ & $\$ 2161$ & $7.4 \%$ & $5.4 \%$ & $64.2 \%$ \\
\hline Ceres & $\$ 708605$ & $\$ 4110279$ & $\$ 2219781$ & $\$ 175$ & $\$ 1016$ & $\$ 549$ & $\$ 13$ & $\$ 73$ & $\$ 40$ & $0.4 \%$ & $2.0 \%$ & $1.1 \%$ \\
\hline Clanwilliam & $\$ 735278$ & $\$ 1041805$ & $\$ 2410512$ & $\$ 506$ & $\$ 717$ & $\$ 1659$ & $\$ 23$ & $\$ 32$ & $\$ 75$ & $0.5 \%$ & $0.7 \%$ & $1.7 \%$ \\
\hline George & $\$ 737363$ & $\$ 706744$ & $\$ 1585248$ & $\$ 2404$ & $\$ 2304$ & $\$ 5169$ & $\$ 6$ & $\$ 5$ & $\$ 12$ & $0.1 \%$ & $0.1 \%$ & $0.3 \%$ \\
\hline Ladismith & $\$ 760912$ & $\$ 1594978$ & $\$ 4002367$ & $\$ 333$ & $\$ 699$ & $\$ 1754$ & $\$ 55$ & $\$ 115$ & $\$ 287$ & $1.9 \%$ & $4.0 \%$ & $10.1 \%$ \\
\hline Laingsburg & $\$ 320279$ & $\$ 1123718$ & $\$ 2657307$ & $\$ 94$ & $\$ 328$ & $\$ 776$ & $\$ 51$ & $\$ 178$ & $\$ 422$ & $2.2 \%$ & $7.9 \%$ & $18.6 \%$ \\
\hline Montagu & $\$ 152215$ & $\$ 1083384$ & $\$ 438919$ & $\$ 222$ & $\$ 1577$ & $\$ 639$ & $\$ 5$ & $\$ 35$ & $\$ 14$ & $0.2 \%$ & $1.4 \%$ & $0.6 \%$ \\
\hline Namakwaland & $\$ 1471425$ & $\$ 2769724$ & $\$ 10664028$ & $\$ 50$ & $\$ 94$ & $\$ 363$ & $\$ 19$ & $\$ 35$ & $\$ 135$ & $0.6 \%$ & $1.2 \%$ & $4.5 \%$ \\
\hline Oudtshoorn & $\$ 2376910$ & $\$ 898330$ & $\$ 7392735$ & $\$ 2905$ & $\$ 1098$ & $\$ 9035$ & $\$ 27$ & $\$ 10$ & $\$ 85$ & $0.8 \%$ & $0.3 \%$ & $2.5 \%$ \\
\hline Prince Albert & $\$ 300572$ & $\$ 359254$ & $\$ 1815741$ & $\$ 178$ & $\$ 213$ & $\$ 1074$ & $\$ 30$ & $\$ 36$ & $\$ 180$ & $2.1 \%$ & $2.5 \%$ & $12.8 \%$ \\
\hline Riversdal & $\$ 610033$ & $\$ 785463$ & $\$ 2092916$ & $\$ 1304$ & $\$ 1679$ & $\$ 4474$ & $\$ 21$ & $\$ 27$ & $\$ 73$ & $0.6 \%$ & $0.8 \%$ & $2.2 \%$ \\
\hline Robertson & $\$ 113301$ & $\$ 808559$ & $\$ 234249$ & $\$ 333$ & $\$ 2373$ & $\$ 687$ & $\$ 3$ & $\$ 23$ & $\$ 7$ & $0.1 \%$ & $0.6 \%$ & $0.2 \%$ \\
\hline Steytlerville & $\$ 560281$ & $\$ 501372$ & $\$ 4198752$ & $\$ 370$ & $\$ 331$ & $\$ 2772$ & $\$ 98$ & $\$ 88$ & $\$ 736$ & $4.7 \%$ & $4.2 \%$ & $35.3 \%$ \\
\hline Sutherland & $\$ 745144$ & $\$ 1620973$ & $\$ 6382525$ & $\$ 157$ & $\$ 341$ & $\$ 1344$ & $\$ 179$ & $\$ 390$ & $\$ 1534$ & $4.2 \%$ & $9.2 \%$ & $36.2 \%$ \\
\hline Swellendam & $\$ 669559$ & $\$ 694355$ & $\$ 2966474$ & $\$ 1234$ & $\$ 1279$ & $\$ 5466$ & $\$ 17$ & $\$ 17$ & $\$ 74$ & $0.4 \%$ & $0.4 \%$ & $1.7 \%$ \\
\hline Uniondale & $\$ 260278$ & $\$ 467839$ & $\$ 1149103$ & $\$ 437$ & $\$ 785$ & $\$ 1929$ & $\$ 24$ & $\$ 43$ & $\$ 106$ & $1.1 \%$ & $1.9 \%$ & $4.7 \%$ \\
\hline Vanrhynsdorp & $\$ 1327392$ & $\$ 1691785$ & $\$ 8743730$ & $\$ 152$ & $\$ 194$ & $\$ 1000$ & $\$ 86$ & $\$ 110$ & $\$ 568$ & $2.6 \%$ & $3.3 \%$ & $16.9 \%$ \\
\hline Vredendal & $\$ 810349$ & $\$ 657839$ & $\$ 3864620$ & $\$ 359$ & $\$ 291$ & $\$ 1712$ & $\$ 24$ & $\$ 20$ & $\$ 114$ & $0.5 \%$ & $0.4 \%$ & $2.4 \%$ \\
\hline Willowmore & $\$ 588792$ & $\$ 569359$ & $\$ 4737193$ & $\$ 285$ & $\$ 276$ & $\$ 2295$ & $\$ 48$ & $\$ 46$ & $\$ 386$ & $3.3 \%$ & $3.2 \%$ & $26.9 \%$ \\
\hline Worcester & $\$ 187793$ & $\$ 1672276$ & $\$ 406791$ & $\$ 263$ & $\$ 2339$ & $\$ 569$ & $\$ 1$ & $\$ 11$ & $\$ 3$ & $0.0 \%$ & $0.2 \%$ & $0.1 \%$ \\
\hline Total & $\$ 19121448$ & $\$ 27284746$ & $\$ 114730665$ & & & & & & & & & \\
\hline Mean & & & & $\$ 635$ & $\$ 907$ & $\$ 2314$ & $\$ 49$ & $\$ 72$ & $\$ 338$ & $1.7 \%$ & $2.4 \%$ & $11.7 \%$ \\
\hline
\end{tabular}

gross economic value summed for a district divided by the population for that district (based on the proportional area of the Succulent Karoo biome in each district). This measure represents the value of the ecosystem service relative to the total value being generated by an individual in the economy.

\subsection{Value of the grazing service}

The natural vegetation of the Succulent Karoo region has been used for its grazing services for the last 2000 years (Deacon et al., 1978; Smith, 1983). Whilst the indigenous pastoralists employed strongly seasonal practices, moving livestock between biomes, colonisation and changes in land tenure practices constrained livestock movements in the last 2 centuries leading to sedentary grazing and degradation of this service (Archer, 2000; Beinart, 2003; Hoffman and Rohde, 2007). Overstocking with a variety of livestock types has further compounded this degradation leading to changes in vegetation community composition (Todd and Hoffman, 1999; Anderson and Hoffman, 2007; Thompson et al., 2009). Grazing services are now more tightly coupled to rainfall, predisposing farmers to greater risk, decreased production and higher mortality rates under drought conditions (Anderson and Hoffman, 2007; Richardson et al., 2007). Determining grazing services values allows for more informed decision making, and potential leverage in steering grazing practices towards sustainability.

We valued grazing, the largest and single most important input required for the extensive livestock industry in the Succulent Karoo, as equivalent to the gross production value of livestock. We decided to adopt this approach rather than a marginal approach to the valuation which we considered to be equally flawed as it assumes a given profit level for a farmer, with the magnitude of this assumption having direct impact on the final value of the service. We converted the 2002 National Agricultural Census count data (Statistics South Africa, 2002) for all livestock - beef cattle, sheep, goats and ostriches - to numbers of large stock units (LSU) by means of the daily metabolic energy demand for a homogenised or 'typical animal' based on the following formula $293 \mathrm{~kJ} / \mathrm{kg}{ }^{0.75}$ (Van der Merwe and Smith, 1991) where an LSU is taken as a $450 \mathrm{~kg}$ heifer. All animal numbers were converted to the number of LSUs per magisterial district. A representative price for LSUs was calculated for each magisterial district by means of proportional abundance across the different animal types.

In developing a practical broad understanding of the value of this service we adopted three different approaches in estimating the value per unit of the grazing service, contrasting non-sustainable with sustainable grazing practices. The first approach drew on the 2002 Agricultural census stock counts as a basis from which to multiply the proportional price per LSU with the real or actual number of LSUs per district to obtain a derived value for the district. This scenario reflects the prevailing non-sustainable situation highlighted above (we call this the REAL scenario). The second approach took recommended long term sustainable stock rates from Scholes (1998) in $\mathrm{km}^{2} / \mathrm{LSU}$, and multiplied these with the representative LSU price to derive the recommended value for each district assuming that grazing was the only land-use practice (we call this the SUSTAINABLE scenario). Our third approach estimated the substitution or replacement value of grazing via a drought relief-support scenario of the current or real situation (we call this the SUBSTITUTION scenario). We estimated this by adopting the South African Department of Agriculture's recommended drought relief diet of $0.25 \mathrm{~kg}$ of maize and $1.75 \mathrm{~kg}$ of lucern per small stock unit per day (Van der Merwe and Smith, 1991). This third scenario is equivalent to measures undertaken during emergency drought conditions in this area and represents the substitution value of natural vegetation as fodder, but also presents a value estimate of expected losses if overstocking continues and eventually requires farmers to provide livestock with an alternative food source to natural vegetation. This scenario is not feasible over the long term, but it provides a necessary possible upper level value for the grazing service here. At current market prices, which have historically been stable for maize (\$275/t) and lucern (\$175/t), an LSU 
maintenance diet would cost approximately \$ 1.95 per day for a $100 \%$ grazing substitution scenario. If we assume a permanent substitution (365 days per year) then the annual substitution value is $\$ 711$ per LSU. From these three approaches we calculated a $\$ / \mathrm{km}^{2}$ value for each district as well as a proportional value that relates to the area of the district that falls within the Succulent Karoo biome, and a per capita grazing value for each district.

The real and the sustainable scenarios produced similar absolute values of $\$ 19$ million and $\$ 27$ million respectively for the Succulent Karoo biome (Table 1), which can be interpreted as minimum values for this service. Here the value from the hypothetical sustainable grazing scenario is higher that the real scenario as it considered the entire biome as having grazing potential. In reality areas may not be used for livestock production. The value estimate derived from the grazing substitution scenario, was significantly larger at \$ 115 million for the biome - the maximum value. This scenario produced the highest values for all of the districts assessed in the Succulent Karoo (Table 1). We have a high degree of confidence in this figure since it is based on a legitimate fodder replacement value but recognise that is could not be realised in practice.

Comparing proportional annual values at a district level with \$ per $\mathrm{km}^{2}$ estimates, those districts with the highest values (Calvinia, Namaqualand) fall to middle and lower order estimated respectively. The difference in grazing values per district is the outcome of significant variation in both the absolute value estimates (i.e. intermethod comparisons) and the relative values (i.e. inter district comparisons). The values per unit surface area provide low estimates for grazing services; however, these services are vital for those individuals whose livelihoods depend primarily on their livestock. The potentially misleading nature of these values becomes apparent on examination of the per capita values for the grazing service (Table 1) which implying almost no value at the individual level. All three methods show that the grazing service is an important economic component in the Succulent Karoo, especially for districts with low potential for intensive agriculture (e.g. Calvinia, Sutherland and Steytlerville).

Whilst we acknowledge that degradation is a highly complex and contested issue (Gillson and Hoffman, 2007), there is sufficient evidence that excessive demand and sustained heavy grazing has damaged the natural capital of the area and the services that flow from it (Reyers et al., 2009). REAL grazing scenario values can be expected to fall over time as degradation continues, resulting in lower stocking rates or higher input costs. The high values of the SUBSTITUTION scenario may resonate with beneficiaries of this service, given that they follow such a strategy under conditions of drought. Without any changes to land-use practices and under continuing conditions of climate change degraded areas are likely to become less productive, with the plants experiencing greater stress due to increased air and soil temperatures, decreased soil moisture availability and the continued loss of moisture, organic matter and nutrients from the system. Reversing these effects is extremely difficult, and requires returning nutrients and organic matter to the system and re-capturing the rainwater and reducing stocking rates. High restoration input costs relative to livestock profits are also likely to make large scale restoration activities difficult and unfeasible (Herling et al., 2009). Considering the relative importance of this service to many beneficiary groups (many of whom are very vulnerable) this is an enormous concern for the region's future.

\subsection{Value of the tourism service}

Understanding tourism as an ecosystem service requires the identification of the biodiversity, ecosystem and landscape features or assets that drive tourism (tourism value attributes) as well as the socio-economic features that drive its promotion and development. This has been both locally and internationally recognised as extremely difficult to achieve (Balmford et al., 2008; Shackleton et al., 2008). This is particularly the case when the tourism service is multidimensional and not one-dimensional like bird watching or scuba diving (Balmford et al., 2008). Placing monetary values on these assets in a valuation exercise provides a further challenge.

Our objective was to assess the relative value of ecosystem service delivery to the tourism industry. In doing so we estimated the financial value of key tourism service features as a proxy value for the ecosystem service. Tourism services in the Succulent Karoo biome are characterised by 'flower viewing', 'scenery' and the 'remoteness' of the region. This division was largely based on climate conditions across the study area (see O'Farrell et al., 2010). None of these services are directly captured by formal markets, and hence there are no market prices for these features. We were therefore unable to use the same approach we adopted in assessing grazing services for the extensive livestock industry. Instead, we used tourist expenditure, measured as the total daily expenditure (TDE), as the basis for estimating the value of tourism as an ecosystem service in the biome. We applied the TDE profile as developed by Thornton and Feinstein (Thornton and Feinstein, 2003) for the adjacent Western Cape region of South Africa. This profile breaks TDE down to five different categories: transport $42 \%$, accommodation $22 \%$, food and drink $24 \%$, entertainment $8 \%$, other $4 \%$. We used an average TDE of $\$ 80.25$, from four tourism valuation studies that had been conducted in the broader Succulent Karoo biome (Thornton and Feinstein, 2003; Turpie and Joubert, 2004; Blignaut et al., 2006; James et al., 2007). These values reflect actual expenditure of tourists in the Western Cape. The average value obtained may be seen as maximum estimate for TDE. These values were multiplied with the average number of bed nights ( 5.2 bed-nights based on Thornton and Feinstein, 2003; Turpie and Joubert, 2004; Blignaut et al., 2006; James et al., 2007), to obtain an estimate of the total expenditure per tourist per year.

Given the heterogeneity of the Succulent Karoo, a variety of features attract different types, and varying numbers of tourists at different times of the year. We could not assume (as in the case of TDE) that all districts were equally important in terms of relative attractiveness for tourists. We divided the Succulent Karoo into two attraction categories, 'flower viewing' and 'scenery'. Five of the 21 districts were categorised as 'flower viewing' districts while 13 districts were categorised as 'scenic' areas (see Table 2). Three districts (Laingsberg, Sutherland, Steytlerville) were excluded from the analysis as they did not lie along any major scenic tourism route; nor could they be classified as flower viewing areas.

Visitor numbers for the 'flower tourism' region were estimated at $21000 \mathrm{pa}$, based on two regional studies (Turpie and Joubert, 2004; James et al., 2007), and data provided by a regional tourism office. Visitor numbers for the 'scenic tourism' region were based on the number of visitors to a popular scenic attraction (the CangoCaves in the Oudtshoorn area) which receives 400,000 visitors per year. This attraction was used as a proxy given the central location of this feature in relation to the main tourism route, the nature of this route and the local fame of the attraction. The total annual tourism value for each tourism category was obtained by multiplying the TDE, bed-nights and number of tourists per year. We obtained an annual value of $\$ 8.9$ million for the 'flower viewing' region, and \$ 167 million for the 'scenic' tourism region.

Large areas within the Succulent Karoo receive very few tourists, and a great deal of this region is not visible from favoured tourism routes. In translating tourism values into spatial units only areas visible from roads, or viewsheds, can be used to calculate the total tourism value for a particular district (Reyers et al., 2009; O'Farrell et al., 2010). Based on the approach adopted by Reyers et al. (2009), 
Table 2

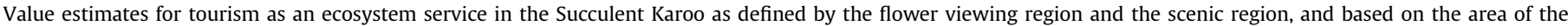

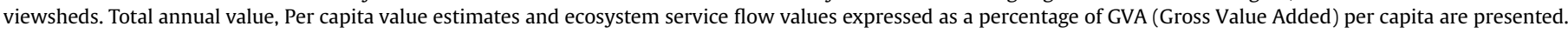
Highlighted districts are conservation priority areas.

\begin{tabular}{|c|c|c|c|c|c|c|}
\hline \multirow[b]{2}{*}{$\begin{array}{l}\text { Magisterial District } \\
\text { Calitzdorp }\end{array}$} & \multicolumn{2}{|c|}{ Total annual value for the SK per district (\$) } & \multicolumn{2}{|c|}{$\begin{array}{l}\text { Values of tourism in the SK portion } \\
\text { of the district ( } \$ \text { per capita) }\end{array}$} & \multicolumn{2}{|c|}{$\begin{array}{l}\text { Ecosystem service flow estimates } \\
\text { (value as \% of GVA per capita) }\end{array}$} \\
\hline & Flower tourism $\left(\$ 166 / \mathrm{km}^{2}\right)$ & $\begin{array}{l}\text { Scenic tourism }\left(\$ 6799 / \mathrm{km}^{2}\right) \\
\$ 1686113\end{array}$ & Flower tourism & $\begin{array}{l}\text { Scenic tourism } \\
\$ 23.7\end{array}$ & Flower tourism & $\begin{array}{l}\text { Scenic tourism } \\
6.1 \%\end{array}$ \\
\hline Calvinia & $\$ 433594$ & & $\$ 2.5$ & & $0.6 \%$ & \\
\hline Ceres & & $\$ 210764$ & & $\$ 0.5$ & & $0.1 \%$ \\
\hline Clanwilliam & $\$ 85626$ & & $\$ 0.3$ & & $0.1 \%$ & \\
\hline George & & $\$ 890648$ & & $\$ 0.8$ & & $0.1 \%$ \\
\hline Ladismith & & $\$ 3596588$ & & $\$ 32.3$ & & $9.0 \%$ \\
\hline \multicolumn{7}{|l|}{ Laingsburg } \\
\hline Montagu & & $\$ 659488$ & & $\$ 2.7$ & & $0.8 \%$ \\
\hline Namakwaland & $\$ 1414230$ & & $\$ 2.2$ & & $0.6 \%$ & \\
\hline Oudtshoorn & & $\$ 3297439$ & & $\$ 4.8$ & & $1.1 \%$ \\
\hline Prince Albert & & $\$ 1890078$ & & $\$ 23.4$ & & $13.3 \%$ \\
\hline Riversdal & & $\$ 20397$ & & $\$ 0.1$ & & $0.0 \%$ \\
\hline Robertson & & $\$ 1216993$ & & $\$ 4.4$ & & $0.9 \%$ \\
\hline \multicolumn{7}{|l|}{ Steytlerville } \\
\hline \multicolumn{7}{|l|}{ Sutherland } \\
\hline Swellendam & & \$1 393763 & & $\$ 4.4$ & & $0.8 \%$ \\
\hline Uniondale & & $\$ 3045882$ & & $\$ 35.2$ & & $12.5 \%$ \\
\hline Vanrhynsdorp & $\$ 321137$ & & $\$ 2.6$ & & $0.6 \%$ & \\
\hline Vredendal & $\$ 17887$ & & $\$ 0.1$ & & $0.0 \%$ & \\
\hline Willowmore & & $\$ 645890$ & & $\$ 6.6$ & & $3.7 \%$ \\
\hline Worcester & & $\$ 965436$ & & $\$ 0.8$ & & $0.1 \%$ \\
\hline Total & $\$ 2272474$ & $\$ 19519478$ & & & & \\
\hline Mean & & & $\$ 1.6$ & $\$ 10.7$ & $0.4 \%$ & $3.7 \%$ \\
\hline
\end{tabular}

we restricted viewing distances to a $10 \mathrm{~km}$ zone along the primary and secondary road networks for areas within the Succulent Karoo biome (see O'Farrell et al., 2010). Viewshed areas were used to convert TDE values to $\$ / \mathrm{km}^{2}$ values. Estimates of $\$ 166 / \mathrm{km}^{2}$ for the 'flower tourism' category and $\$ 6799 / \mathrm{km}^{2}$ for the scenic tourism' category were generated using this methodology. These values were multiplied with the viewshed areas of the districts within each category to obtain the districts' total annual value of the tourism ecosystem service value (Table 2). Values were also calculated on a per capita basis (\$ per capita) (Table 2 ).

The results for viewsheds alone indicate significant differences between the value of flower viewing and scenic tourism with total values of $\$ 2.2$ million and \$ 19.5 million respectively (Table 2). However these are not necessarily comparable as they cater to different categories of tourists.

Substantial variation in the estimates for flower tourism and scenic tourism was also evident when examined using a \$ per capita approach (Table 2). The mean per capita value for flower tourism was $\$ 1.6$, while for the scenic tourism the equivalent was $\$ 10.7$ per capita per year. These figures give an indication of the potential of this service to alleviate poverty and diversify livelihoods. The potential is explained when compared to the gross value added (GVA) per district. The values as a percentage of the GVA show much the same patterns. The scenic tourism service has much higher values both per capita and as a percentage of the district GVA. Districts with lower than anticipated percentage of GVA per capita values, were attributed to both larger relative population sizes and a greater diversity of economic activity. The per capita values presented provide an inaccurate picture as only a portion of the population is involved in tourism. Per capita values would be much higher for those engaged in this industry but these numbers are not known.

Our approach and analysis demonstrates both the critical need for better tourism service related data, and the possible or future potential of the tourism industry in improving human wellbeing, diversifying available livelihood options and reducing vulnerability. The number of tourists to a region, and to what degree they engage with ecosystem system service assets, strongly influences the value of the tourism service. Conservative visitor estimates indicate that tourism is not as important as grazing in the Succulent Karoo in terms of value created. Studies in similar environments in Namibia have found that the broader social value of tourism-related ecosystem services is typically underestimated because the valuations do not (a) take into account the fact that employment in the tourism industry often benefits the poorest people most directly (through employment as guides or in accommodation) and (b) that wildlife farming benefits can exceed those from conventional livestock farming (Barnes and Humavindu, 2003). These beneficiary groups can however, be vulnerable to changes in the supply and demand for the tourism ecosystem service.

Our approach was not geared towards capturing the effects that a change in the amount of tourism service features (changes in the number of flowers and change in scenic landscapes) would have on the value of this service. Whilst we have little understanding of this relationship we do know that the supply of annual flower displays which drives demand in parts of our study area is directly coupled to the rainfall in these regions. Annual plant species displays which are the key biodiversity feature, are directly cued by rainfall (Van Rooyen et al., 1990) and decreases in the size of and probability of flower displays are highly likely to result in a decrease in flower tourism to the region (James et al., 2007). Dry years result in poor flower displays and low numbers of tourists. In these years the more vulnerable beneficiaries of this service, those involved in the tourism industry, are severely affected. Furthermore, climate change predictions for this region anticipate decreased rainfall threatening the long term supply of this service (MacKellar et al., 2007). Further constraints to tourism development such as escalating transport costs (Succulent Karoo destinations are remote from major population centres) and, in particular, water demand and supply, also closely coupled to climate change, are discussed in the following section.

\subsection{Value of the water service}

Water is the limiting resource for semi-arid and arid systems like the Succulent Karoo biome. It controls and constrains all 
aspects of life in the region from primary production in ecosystems through to the future economic development potential of the area. Despite its importance there have been few detailed studies of the hydrology of this region. The natural flows in the river systems of the Succulent Karoo are highly erratic with marked temporal and spatial variability even in the larger rivers (Görgens and Hughes, 1982).

The valuation of water is complicated by its fundamental role in sustaining all life. The upper level value of water is, therefore, the value of life which is generally viewed as having cultural and moral dimensions which make reducing it to a monetary value, or price, highly controversial. The valuation of water is further complicated by the fact that little consensus exists on the appropriate method for estimating the value of the water service and the public goods nature of many benefits derived from water (Blignaut \& De Wit, 2004; Birol et al., 2006; United Nations, 2006). One approach in determining price is to use market prices or, preferably, marginal values to deduce a price; however the inelastic demand for this resource makes this type of approach invalid (Nieuwoudt et al., 2004). A further suggested approach to deriving an economic value is to estimate how much value is added per unit of water. This can be relatively easily estimated for agricultural products where there is a market and the water inputs are reasonably well understood so the returns per unit of water can be calculated (e.g. Hassan and Okbrich, 1999; Lange et al., 2007). But measuring water's contribution to all sectors, to the total value chain of a good or service, or its total economic benefit is far more complex (Hassan and Okbrich, 1999; Crafford et al., 2004; Nieuwoudt et al., 2004; Moolman et al., 2006; United Nations, 2006). Furthermore such analysis should also include the demand for water from the ecosystems themselves. An analysis of this kind for the Succulent Karoo is potentially feasible but was beyond the possible bounds of this study.

We calculated an upper and lower estimate for the value of water in the study area based on two approaches. We adopted a cost recovery approach (Lange and Hassan, 2006) in determining a minimum estimate for the value of the water services of the Succulent Karoo which excludes any benefits or value derived from that water, and ignores the role that ecosystems play in the supply of water. In addition to this method we estimated the total value of the economy (GVA) as an indication of the upper value of the water services, and therefore includes those benefits and the ecological role that it plays excluded by the cost recovery approach. We acknowledge that attributing GVA to water when water is only one of several inputs is incorrect; the GVA is derived from several inputs and will, therefore, overestimate the value of water. Using the GVA also involves double counting where for example water is valued for the grazing it provides to livestock and the livestock sales are reflected in the total GVA. However, water is arguably the one input without which there would be no economic activity so the GVA per unit of water is arguably closer to the upper bound of water's economic value to society than the cost of water provision.

The cost recovery approach value estimate was based on a unit reference value (URV) for water provisioning multiplied by the volume of water (annual yield) of the supply infrastructure. Infrastructure includes formal infrastructure used by water user associations and municipalities, and informal infrastructure like private boreholes or even communal water supply mechanisms. We defined the URV as the present value of all costs (PVC), divided by the present value of all of yields or savings and benefits (PVB) incurred over the economic life span of the water supply infrastructure. Total yield is estimated by multiplying the expected annual yield with the supply scheme/infrastructure life span. This value is presented in a volumetric unit $\left(\$ / \mathrm{m}^{3}\right)$ and is considered to be a minimum estimate of the relative value of water. URV is therefore a reversed benefit cost ratio $(B C R),(B C R=1 / U R V)$. This value should only be used for comparing the different water supply alternatives in the same region, since the actual values of a unit of water vary widely in the different areas and the accepted cost per $\mathrm{m}^{3}$ will differ as well. In addition the URV is heavily dependant on the consistency of counting all the different cost and benefits that occur over the set life span of the supply scheme, which is debatable too.

We extracted data from a provincial survey (De Lange, 2006) on water user associations in the Western Cape to obtain estimates regarding tariffs and volumes relevant to our study area. The survey excluded the City of Cape Town metropolis, but still represented $53.1 \%$ of all municipal and agricultural water use in the Western Cape (De Lange and Kleynhans, 2007, 2008). Cost data relating to the type of bulk supply infrastructure, source of supply, number of members, enlistment, types of user and annual tariffs were obtained from water user associations relevant to our study area (De Lange, 2006). A distinction was made between serviced and raw water, with the former being significantly more expensive because of additional built in services (filtration, chlorination, stabilisation and pressurisation). Borehole water was handled separately. Cost estimates for each source were based on survey data and reconciled with unpublished estimates from the Western Cape provincial department of Agriculture's engineering services unit (De Lange, 2006).

We calculated from the survey data (De Lange, 2006) that $85.3 \%$ of the surface water consumed in the study area is sold as raw surface water at $\$ 0.018 / \mathrm{m}^{3}$ while the remaining $14.7 \%$ is supplied as serviced water at $\$ 0.674 / \mathrm{m}^{3}$. Ground water was supplied at $\$$ $0.106 / \mathrm{m}^{3}$ as raw water. The weighted average (volumetric weighted) cost recovery value of surface water was $\$ 0.115 / \mathrm{m}^{3}$ for the survey. These estimates were multiplied with annual surface and ground water yield estimates obtained at quaternary catchment level. Values are also expressed on a per capita basis.

We valued water for the Succulent Karoo to range approximately between $\$ 300$ million and $\$ 3.1$ billon using the cost recovery and GVA approaches respectively (Table 3 ). The cost recovery method results in substantial values being attributed to areas with formal water supply systems (Table 3 ). Districts with high usage of water for irrigated farming stood out (Worcester, Clanwilliam, Ceres). When the GVA is used as the value basis, the districts with the largest economies emerge with the highest water values (George, Worcester). Districts with the lowest values are found in either the driest regions (Namaqualand) or in the weakest economies (Laingsburg). Again, there is significant variation in both the absolute and relative value estimates provided by the two methods.

The mean per capita value for water using the cost recovery approach was \$458, while the GVA approach yielded \$ 3283 per capita per year. The per capita cost recovery basis, identified a different set of districts with the highest water values (Ceres, Clanwilliam, Laingsburg, Sutherland, Calitzdorp) (Table 3). This differs from the distribution of the total annual value and the unit area values. Examining the GVA per capita values, again yielded a different suite of districts with the highest values (Vredendal, Worcester, George, Swellendam) and the lowest values (Prince Albert, Willowmore). When the cost recovery is expressed as a percentage of the GVA, yet another combination of districts emerges as deriving the most value from water on a per capita basis (Laingsburg, Ceres, Clanwilliam, Prince Albert Districts) and the least on a per capita basis (Swellendam, Vredendal, George).

None of these statistics expressed in our approach highlights the problems of the limited water resources very effectively, as they are all a function of the volumes of water available. What is important is not the absolute value, but what proportion it represents of the total available and the total demand, and how sensitive the amount 
Table 3

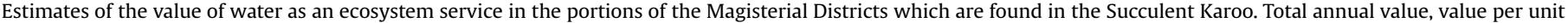
area, per capita values and flow values estimated as a \% of GVA (Gross Value Added) per capita are presented. Highlighted districts are conservation priority areas.

\begin{tabular}{|c|c|c|c|c|c|c|c|c|}
\hline \multirow[b]{2}{*}{ Magisterial District } & \multicolumn{2}{|c|}{ Total annual value $(\$)$} & \multicolumn{2}{|c|}{ Unit area values $\left(\$ / \mathrm{km}^{2}\right)$} & \multicolumn{2}{|c|}{$\begin{array}{l}\text { Value of the service (\$ per } \\
\text { capita) }\end{array}$} & \multicolumn{2}{|c|}{$\begin{array}{l}\text { Ecosystem service flow } \\
\text { values (\% of GVA per } \\
\text { capita) }\end{array}$} \\
\hline & Cost Recovery & GVA & Cost Recovery & GVA & Cost Recovery & GVA & Cost Recovery & GVA \\
\hline Calitzdorp & $\$ 5612250$ & $\$ 27523250$ & $\$ 4983.50$ & $\$ 24440$ & $\$ 630.3$ & $\$ 3090.8$ & $20 \%$ & $100 \%$ \\
\hline Calvinia & $\$ 12076523$ & $\$ 71673500$ & $\$ 463.38$ & $\$ 1929$ & $\$ 566.9$ & $\$ 3364.0$ & $17 \%$ & $100 \%$ \\
\hline Ceres & $\$ 83540720$ & $\$ 200762500$ & $\$ 8500.25$ & $\$ 20420$ & $\$ 1485.1$ & $\$ 3568.9$ & $42 \%$ & $100 \%$ \\
\hline Clanwilliam & $\$ 50380392$ & $\$ 140033000$ & $\$ 8783.88$ & $\$ 18947$ & $\$ 1567.6$ & $\$ 4357.3$ & $36 \%$ & $100 \%$ \\
\hline George & $\$ 4287075$ & $\$ 620915500$ & $\$ 3296.13$ & $\$ 253262$ & $\$ 31.9$ & $\$ 4621.9$ & $1 \%$ & $100 \%$ \\
\hline Ladismith & $\$ 5565789$ & $\$ 39761750$ & $\$ 1520.38$ & $\$ 10861$ & $\$ 399.5$ & $\$ 2854.4$ & $14 \%$ & $100 \%$ \\
\hline Laingsburg & $\$ 6246089$ & $\$ 14271375$ & $\$ 830.38$ & $\$ 1632$ & $\$ 991.5$ & $\$ 2265.3$ & $44 \%$ & $100 \%$ \\
\hline Montagu & $\$ 7965000$ & $\$ 79422250$ & $\$ 3302.00$ & $\$ 32203$ & $\$ 260.1$ & $\$ 2593.8$ & $10 \%$ & $100 \%$ \\
\hline Namakwaland & $\$ 2960550$ & $\$ 234976750$ & $\$ 61.50$ & $\$ 4861$ & $\$ 37.5$ & $\$ 2978.8$ & $1 \%$ & $100 \%$ \\
\hline Oudtshoorn & $\$ 18699549$ & $\$ 294724875$ & $\$ 5558.75$ & $\$ 87531$ & $\$ 215.6$ & $\$ 3398.5$ & $6 \%$ & $100 \%$ \\
\hline Prince Albert & $\$ 4741620$ & $\$ 14166500$ & $\$ 995.75$ & $\$ 1741$ & $\$ 470.3$ & $\$ 1404.9$ & $34 \%$ & $100 \%$ \\
\hline Riversdal & $\$ 1795931$ & $\$ 97240250$ & $\$ 2159.63$ & $\$ 24779$ & $\$ 62.4$ & $\$ 3377.9$ & $2 \%$ & $100 \%$ \\
\hline Robertson & $\$ 7314760$ & $\$ 135070875$ & $\$ 4764.75$ & $\$ 84383$ & $\$ 211.4$ & $\$ 3903.6$ & $5 \%$ & $100 \%$ \\
\hline Steytlerville & $\$ 2220850$ & $\$ 11884625$ & $\$ 639.25$ & $\$ 3317$ & $\$ 389.1$ & $\$ 2082.1$ & $19 \%$ & $100 \%$ \\
\hline Sutherland & $\$ 3767254$ & $\$ 17652750$ & $\$ 438.25$ & $\$ 1954$ & $\$ 905.6$ & $\$ 4243.5$ & $21 \%$ & $100 \%$ \\
\hline Swellendam & $\$ 1008984$ & $\$ 176838625$ & $\$ 913.25$ & $\$ 43661$ & $\$ 25.3$ & $\$ 4436.0$ & $1 \%$ & $100 \%$ \\
\hline Uniondale & $\$ 5379191$ & $\$ 24337250$ & $\$ 2319.50$ & $\$ 7893$ & $\$ 497.6$ & $\$ 2251.6$ & $22 \%$ & $100 \%$ \\
\hline Vanrhynsdorp & $\$ 2804241$ & $\$ 51792875$ & $\$ 293.88$ & $\$ 5428$ & $\$ 182.3$ & $\$ 3365.1$ & $5 \%$ & $100 \%$ \\
\hline Vredendal & $\$ 1036662$ & $\$ 16016625$ & $\$ 284.75$ & $\$ 43629$ & $\$ 30.6$ & $\$ 4739.0$ & $1 \%$ & $100 \%$ \\
\hline Willowmore & $\$ 2457929$ & $\$ 17607875$ & $\$ 631.25$ & $\$ 2290$ & $\$ 200.3$ & $\$ 1434.3$ & $14 \%$ & $100 \%$ \\
\hline Worcester & $\$ 69504398$ & $\$ 690040750$ & $\$ 17194.13$ & $\$ 170047$ & $\$ 464.8$ & $\$ 4613.5$ & $10 \%$ & $100 \%$ \\
\hline Total & $\$ 299365755$ & $\$ 3120861750$ & & & & & & \\
\hline Mean & & & $\$ 3234.98$ & $\$ 40248$ & $\$ 458.4$ & $\$ 3283.1$ & $16 \%$ & $100 \%$ \\
\hline
\end{tabular}

available is to variability in rainfall and the state of the land and ecosystems (Le Maitre et al., 2007a). In the Succulent Karoo the demand exceeds the amount available and the amount is very dependent on rainfall, especially during extended droughts (Le Maitre \& O'Farrell, 2008). Despite the discrepancies between valuation methods and approaches it is clear that even if we are considering only minimum values, the water services make a substantial contribution to this region, especially in contrast to the values estimated for tourism and grazing.

Water service values generated in this study have potential to advance sustainable land management agendas in the districts for which high values exist. Water services also play an overarching role in determining many other services related to the agricultural economy of an arid system including soil conservation and nutrient cycling, and in turn, the services of primary production and water provision (Safriel et al., 2005). Therefore promoting catchment integrity to maximise water flows would see the sustainable management of grazing, and in turn the preservation of key ecological elements such as vegetation and soil crusts integrity (Belnap and Lange, 2003), and these in turn are likely to also tie in closely to other regulating and provisioning services (Le Maitre et al., 2007a; Reyers et al., 2009). Increasing population and economic growth will increase demand for this service, however supply, already constrained is most likely to decrease, and innovative approaches to demand side management of this services will become vital in the future.

\section{Valuation for conservation and sustainable management}

As Redford and Adams (2009) point out the conservation community is increasingly reliant on the concept of ecosystem services as they try to make a case for the importance of nature and its conservation to a sceptical audience of decision and policy makers. This study represents an attempt to enhance the conservation program in the Succulent Karoo biome with more information on the value of the biome to human wellbeing and economies.
In these cases one's hope to end up at the upper end of the valuation scale, where services have high value and can potentially compete with opportunity costs and other costs often associated with conservation. In these instances, and where spatial and institutional arrangements align, there would be potential for establishing PES and other incentive schemes to direct certain conservation land-use behaviours and practices. However, while the study area is certainly rich in unique fauna and flora, the same cannot be said for its ecosystem services. The Succulent Karoo biome ecosystem services values are at the lower end of the scale when compared with global studies such as Costanza et al. (1997) and Turner et al. (2007), studies in other more mesic biodiversity hotspots (Wendland et al., 2009), and even other studies in South Africa (see Le Maitre et al., 2007b; Blignaut et al., 2008). It is important to note that comparisons are constrained by the diverse range of valuation methods used in the literature as well as the lack of studies carried out in other arid and semi-arid regions. These lower end values, which compare less favourably with the costs of conservation than in other parts of the country or world, make it more challenging to gain international and national support for conservation or to set up incentive schemes.

Despite their poor appeal at national and international scales, these regional assessments and valuations in arid areas are useful in that they allow for comparisons within a region, highlight the spectrum of services values and when communicated correctly can emphasise the need for careful management of these services. We discuss three ways below in which lower values in arid systems can still be useful in promoting conservation and sustainable management.

First, where there is congruence with conservation priority areas ecosystem services (even at the lower end of values) can add weight to the conservation case. In this study for example, the 10 priority conservation districts all stand out as having some of the highest values for one or more services. Whilst there is some variation dependent on valuation approach and the way the value is expressed, priority districts consistently appear in the top third of 
valuations. Of these conservation priority districts three (Worcester, Robertson, Oudtshoorn) are important in terms of their water service values (Table 3), while seven (Calvinia, Ladismith, Oudtshoorn, Sutherland, Namaqualand, Vanrynsdorp, Vredendal) are important for their grazing service values (Table 1), one (Namaqualand) for its flower-related tourism values and three (Ladismith, Calitzdorp, Oudtshoorn) for their scenic tourism values (Table 2). There is potential for conservation efforts in these districts to use particular ecosystem services to make their case (with the right communication tools) for more careful management and decision making.

Second, as ecosystem services seldom respect administrative boundaries and ecosystem services in arid regions require careful management, regional level analyses can enable the development of agreements between administrative units regarding ecosystem service supply. This could lead to a district-level policy for the adoption of a PES scheme, where payments are made via a district or promoted by a district and paid by a third party like a conservation organisation to landowners for adopting sustainable landuse practices. For example land-use practices in districts in upper river catchments affect down stream users in other districts (Le Maitre \& O'Farrell, 2008). Inter-district level agreements are required to ensure understanding between service suppliers and beneficiaries in these cases.

Third, being able to depict where ecosystem services are provided, who benefits and by how much, can be quite powerful informers of land and resource use decision making. While the economic values of ecosystem services in arid areas may not be comparable to the value of other industries, decision makers especially in arid areas, are concerned about water, social development targets and vulnerable populations. By conducting an assessment of ecosystem service values in such a spatially explicit manner at the local land-use decision making scale, studies such as these have tremendous potential to inform decisions. In this case the water and grazing services, their value in the regional economy, and their declining state would be useful information for decision makers. The challenge now remains to find ways of mainstreaming this information into the tools and approaches used by decision makers (Cowling et al., 2008; Reyers et al., 2010). In South Africa this would include the Spatial Development Framework - a spatial depiction of the future development trajectory of the region. Currently these instruments are constrained by inadequate data, lack of consultation and capacity challenges, but much of the work done in this pragmatic study would be possible in most parts of the country and would strengthen these planning tools significantly.

In conclusion, it would appear that the scale of approach is important. While a regional scale demonstrates significant use in land-use decision making as highlighted above, the national or international scale is less useful in land-use decisions, but potentially powerful in directing resources and political will. This is also evident when reflecting on the 'value' of a service where perceptions and values are likely to differ between, for example, national politicians and local farmers. Here the idea of how and where one chooses to 'bound' a study, and in turn what and whose perspective is being valued is evidently significant. Furthermore, such valuations should engage the audience that one is trying to influence (Cowling et al., 2008).

\section{Valuation implications for wellbeing}

People living the Succulent Karoo, particularly those in communal areas and rangelands who have historically been marginalised, have low income levels (Berzborn, 2007; Hoffman et al., 2007). While ecosystem service values may be low, there is a tightly coupled dependence between the people living in this region and the services provided by the region (James et al., 2005; Allsopp et al., 2007; Richardson et al., 2007). For example, although grazing service values may be far lower than those in higher rainfall regions, the importance of this service to the lifestyle of people of the Succulent Karoo region goes beyond its economic value (Berzborn, 2007).

In previous studies the link between human wellbeing and ecosystem services has been tied to areas with high levels and values of ecosystem services (e.g. Costanza et al., 1997; Ash et al., 2009). Marginal environments, critical thresholds of service supply and the livelihood and cultural values of ecosystem services are not frequently included in many economic valuation studies. If we adopt the notion that people, wellbeing and ecosystem services are integrally linked, and our goal is to improve human wellbeing, then efforts should also be focussed on these topics and areas with high dependence on even the most marginal of services. Small changes to these landscapes and ecosystems, and the subsequent delivery of services, could have massive positive or negative implications for those dependent on these services.

This vulnerability to small changes in service supply, as well as the consideration of livelihood options in arid regions, provides two helpful avenues for further exploration. The first is the argument in favour of wellbeing or welfare payments linked to threshold levels of supply. Where sustainable management is critical for human wellbeing it raises the possibility for private and public funded PES scheme establishment, particularly those schemes linked to ecosystem restoration and even job creation (Wendland et al., 2009). The case of the Working for Water scheme in South Africa is an example (van Wilgen et al., 1998). When research demonstrated the water use of alien woody plants, particularly in areas of already constrained water availability, this public funded job creation program to remove alien plants was set up and has continued to grow in scope and investment (Turpie et al., 2008). PES schemes can focus on any range of ecosystem service delivery or value and therefore have the potential to contribute to improved wellbeing. A limiting factor is the administrative costs associated with these schemes, which cannot but often does exceed service values, often necessitating public investment. Within the Succulent Karoo the supply of the water and tourism services is to a large degree controlled by the land-use practices of the farmers of this region. Approaches which reward farmers for adopting sustainable land-use practices and new practices which diversify away from a reliance on intensive grazing can increase the potential income achievable under such management regimes and are likely to have positive wellbeing and service spinoffs for this region (Le Maitre et al., 2007a; Le Maitre \& O'Farrell, 2008).

The second argument relates to valuing limited yet strategically important services. The valuation approach that we adopted, particularly the value per unit surface area, indicated that services such as the grazing service in the Succulent Karoo had little value. However, it may have very high value to the beneficiary whose livelihood, for example, depends primarily on their livestock particularly in times of hardship and limited options. Whilst we attempted to overcome these issues by considering per capita values, district level statistics are indiscriminate and service beneficiaries (especially small vulnerable populations) cannot be extracted for the total district population. An identified problem with using mean annual values is that in some cases areas of low ecosystem service supply have a critical role to play at certain times of a year for certain communities. These are typically in marginal and resource impoverished environments, where annual and mean value assessments fail to capture the strategic importance of a marginal resource. Key resource areas are areas which form a critical component of a resource use or land management strategy during a year (Illius and O'Connor, 1999). Farmers have developed 
strategies to exploit specific resources at certain times of the year (O'Farrell et al., 2007). Key resource areas are generally limited in extent and of value at specific times, given their ecology. Once incorporated into annual district level valuations, their critical role in maintaining lifestyles and land-use strategies is lost. Furthermore some areas of low ecosystem service values still provide a diversity of services, enabling communities to diversify their livelihood strategies and reducing vulnerability in hard times (e.g. engaging in tourism activities and livestock production) - here it is diversity rather than amount per service that matters (Berzborn, 2007; O'Farrell et al., 2007). This is significant because it reduces vulnerability in an area of low economic activity and low per capita incomes. Evidently our adopted approach fell well short in recognising important services, valuable service areas, and broader societal 'value'. Approaches such as those focussed on inclusive wealth and the use of resilience measures show promise in filling this gap (Walker et al., 2009). Returning back to the points made about the scale of assessment and valuation, the findings of this study make a strong case for detailed household-level, service-dependence assessments and valuation (Shackleton and Shackleton, 2006). Generating an understanding of demand and supply of a service, as well as understanding the implication of changing services, at a local level, would be highly informative.

\section{Need for improved tools}

This study points to the need for better links between ecological knowledge and social science tools where understanding is integrated. Indicators which measure both ecological function and human wellbeing need to be developed so as to allow for more accurate assessment and in turn monitoring into the future, especially within the context of potential PES schemes. If we are to proceed towards sustainable land-use practices with ecosystem services integrated into land-use and development plans, then socio-economic data collection needs to be informed by ecosystem service assessment requirements. This will also allow for marginal analyses approaches in the future. We need to improve our data capture, valuation and reporting tools, so that the nuances and the detail of service supply and benefit are not lost. We also need robust ways of capturing the non-monetary values that are critical to the sense of identity and belonging that underpin the social structures and cohesion that are needed for individual and communal human wellbeing. Finally, we need some consensus on data, methods and approaches for pragmatic valuation approaches which do not require massive amounts of funding nor take years to be completed, if valuation exercises are to feed into formal PES schemes and other conservation and wellbeing tools where such huge ranges in numbers would be problematic.

\section{References}

Allsopp, N., Laurent, C., Debeaudoin, L.M.C., Samuels, M.I., 2007. Environmental perceptions and practices of livestock keepers on the Namaqualand Commons challenge conventional rangeland management. Journal of Arid Environments 70 (4), 740-754.

Anderson, P.M.L., Hoffman, M.T., 2007. The impacts of sustained heavy grazing on plant diversity and composition in lowland and upland habitats across the Kamiesberg mountain range in the Succulent Karoo, South Africa. Journal of Arid Environments 70 (4), 686-700.

Archer, S., 2000. Technology and ecology in the Karoo: a century of windmills, wire and changing farming practice. Journal of Southern African Studies 26 (4), 675-696.

Ash, N., Blanco, H., Brown, C., Garcia, K., Hendrichs, T., Lucas, N., RuadseppHearne, C., Simpson, R.D., Scholes, R., Tomich, T., Vira, B., Zurek, M., 2009. Ecosystems and Human Well-Being: A Manual for Assessment Practitioners. World Resources Institute, Washington, D.C., USA.

Balmford, A., Cowling, R.M., 2006. Fusion or failure? The future of conservation biology. Conservation Biology 20 (3), 692-695.
Balmford, A., Bruner, A., Cooper, P., Costanza, R., Farber, S., Green, R.E., Jenkins, M., Jefferiss, P., Jessamy, V., Madden, J., Munro, K., Myers, N., Naeem, S., Paavola, J. Rayment, M., Rosendo, S., Roughgarden, J., Trumper, K., Turner, R.K., 2002. Economic reasons for conserving wild nature. Science 297 (5583), 950-953.

Balmford, A., Rodrigues, A.S.L., Walpole, M., ten Brink, P., Kettunen, M., Braat, L., de Groot, R., 2008. The Economics of Ecosystems and Biodiversity: Scoping the Science. European Commission, Cambridge, UK.

Barnes, J.I., Humavindu, M.N., 2003. Economic Returns to Land-Use Options in Gondwana Canyon Park, Karas, Namibia. Environmental Economics Unit Ministry of Environment and Tourism, Namibia, for Nature Investments (Pty) Ltd. Sourced. http://www.span.org.na/Reports\%20\%20and\%20Publications/Conserva tion\%20Needs\%20Assessment.pdf.

Beinart, W., 2003. The Rise of Conservation in South Africa. Settlers, Livestock and the Environment 1770-1950. Oxford University press, Cape Town.

Belnap, J., Lange, O.L., 2003. Biological Soil Crusts: Structure, Function, and Management. Springer-Verlag, Berlin.

Berzborn, S., 2007. The household economy of pastoralists and wage-labourers in the Richtersveld, South Africa. Journal of Arid Environments 70 (4), 672-685.

Birol, E., Karousakis, K., Koundouri, P., 2006. Using economic valuation techniques to inform water resources management: a survey and critical appraisal of available techniques and an application. Science of the Total Environment 365, 105-122.

Blignaut, J.N., De Wit, M., 2004. Sustainable Options: Development Lessons from Applied Environmental Economics. UCT Press, Cape Town.

Blignaut, J.N., Milton, S., Cupido, C.F., 2006. The Economic Value of Controlling Invasive Alien Plant Species in the Succulent and Nama Karoo Biomes of South Africa. Working for Water Programme, Department of Water Affairs and Forestry, Pretoria.

Blignaut, J., Marais, C., Rouget, M., Mander, M., Turpie, J., Klassen, T., Preston, G., 2008. Making Markets Work for People and the Environment: Employment Creation from Payment for Eco-Systems Services Combating Environmental Degradation and Poverty on a Single Budget while Delivering Real Services to Real People. South African Government, Pretoria.

Brauman, K.A., Daily, G.C., Duarte, T.K., Mooney, H.A., 2007. The nature value of ecosystem services: an overview highlighting hydrological services. Annual Review of Environment and Resources 32, 67-98.

CEPF, 2003. The Succulent Karoo hotspots. Namibia and South Africa. Ecosystem profile. Critical Ecosystem Partnership Fund. Conservation International, Washington.

CSIR, 2007. Geospatial Analysis Platform and NSDP Spatial Profiles. Incorporating SA Mesoframe Version 2. The Presidency, dti, GTZ, EDAP. Built Environment CSIR, Pretoria.

Carpenter, S.R., Folke, C., 2006. Ecology for transformation. Trends in Ecology and Evolution 21, 309-315.

Chan, K.M.A., Shaw, M.R., Cameron, D.R., Underwood, E.C., Daily, G.C., 2006 Conservation planning for ecosystem services. Plos Biology 4 (11), 2138-2152.

Chan, K.M.A., Pringle, R.M., Ranganathan, J., Boggs, C.L., Chan, Y.L., Ehrlich, P.R., Haff, P.K., Heller, N.E., Al-Krafaji, K., Macmynowski, D.P., 2007. When agendas collide: human welfare and biological conservation. Conservation Biology 21 (1), 59-68.

Chavas, J.-P., 2000. Ecosystem valuation under uncertainty and irreversibility Ecosystems (3), 11-15.

Costanza, R., 2003. Social goals and the valuation of natural capital. Environmental Monitoring and Assessment 86 (1-2), 19-28.

Costanza, R., dArge, R., deGroot, R., Farber, S., Grasso, M., Hannon, B., Limburg, K. Naeem, S., ONeill, R.V., Paruelo, J., Raskin, R.G., Sutton, P., vandenBelt, M., 1997 The value of the world's ecosystem services and natural capital. Nature 387 (6630), 253-260.

Costanza, R., Fisher, B., Mulder, K., Liu, S., Christopher, T., 2007. Biodiversity and ecosystem services: a multi-scale empirical study of the relationship between species richness and net primary production. Ecological Economics 61 (2-3), 478-491.

Cowling, R.M., Pierce, S.M., 1999. Namaqualand: A Succulent Desert. Fernwood Press, Cape Town.

Cowling, R.M., Esler, K.J., Rundel, P.W., 1999a. Namaqualand, South Africa - an overview of a unique winter-rainfall desert ecosystem. Plant Ecology 142 (1-2) $3-21$.

Cowling, R.M., Esler, K.J., Rundel, P.W., 1999b. Special issue editorial: the plant ecology of Namaqualand, South Africa. Plant Ecology 142 (1-2), 1-2.

Cowling, R.M., Egoh, B., Knight, A.T., O’Farrell, P.J., Reyers, B., Rouget'll, M., Roux, D.J., Welz, A., Wilhelm-Rechman, A., 2008. An operational model for mainstreaming ecosystem services for implementation. Proceedings of the National Academy of Sciences of the United States of America 105 (28), 9483-9488.

Crafford, J.G., Hassan, R.M., King, N.A., Damon, M.C., de Wit, M.P., Bekker, S Rapholo, B.M., Olbrich, B.W., 2004. An Analysis of the Social, Economic, and Environmental Direct and Indirect Costs and Benefits of Water Use in Irrigated Agriculture and Forestry. Report No. 1048/1/04. Water Research Commission, Pretoria.

Daily, G.C., Matson, P.A., 2008. Ecosystem services: from theory to implementation. Proceedings of the National Academy of Sciences of the United States of America 105 (28), 9455-9456.

Daily, G.C., Polasky, S., Goldstein, J., Kareiva, P.M., Mooney, H.A., Pejchar, L, Ricketts, T., Salzman, J., Shallenberger, R., 2009. Ecosystem services in decision making: time to deliver. Frontiers in Ecology and Environment 7, 21-28.

De Lange, W.J., 2006. Multi-criteria Decision-Making for Water Resource Management in the Berg Water Management Area. Stellenbosch University, Stellenbosch. 
De Lange, W., Kleynhans, T.E., 2007. Towards more inclusive long term bulk water resource management. Agrekon 46, 371-397.

De Lange, W., Kleynhans, T.E., 2008. Long-term water resource management in semi-arid areas: a South African case study. International Journal of Sustainable Development and Planning 3,1-19.

Deacon, H.J., Deacon, J., Brooker, M., Wilson, M., 1978. The evidence for herding at Boomplaas Cave in the southern Cape, South Africa. South African Archaeological Bulletin 33, 39-65.

Desmet, P.G., 2007. Namaqualand - a brief overview of the physical and floristic environment. Journal of Arid Environments 70 (4), 570-587.

Egoh, B., Rouget, M., Reyers, B., Knight, A.T., Cowling, R.M., van Jaarsveld, A.S., Welz, A., 2007. Integrating ecosystem services into conservation assessments: a review. Ecological Economics 63 (4), 714-721.

Farley, J., Brown Gaddis, E.J., 2007. Restoring natural capital: an ecological economics assessment. In: Aronson, J., Milton, S.J., Blignaut, J.N. (Eds.), Restoring Natural Capital: Science, Business and Practice. Island Press, Washington DC USA, pp. 17-27.

Fisher, B., Christopher, T., 2007. Poverty cand biodiversity: measuring the overlap of human poverty and the biodiversity hotspots. Ecological Economics 62 (1), 93-101.

Fisher, B., Turner, R.K., 2008. Ecosystem services: classification for valuation. Biological Conservation 141 (5), 1167-1169.

Fisher, B., Turner, K., Zylstra, M., Brouwer, R., de Groot, R., Farber, S., Ferraro, P., Green, R., Hadley, D., Harlow, J., Jefferiss, P., Kirkby, C., Morling, P., Mowatt, S. Naidoo, R., Paavola, J., Strassburg, B., Yu, D., Balmford, A., 2008. Ecosystem Services and economic theory: integration for policy-relevant research Ecological Applications 18 (8), 2050-2067.

Görgens, A.H.M., Hughes, D.A., 1982. Synthesis of streamflow information relating to the semi-arid Karoo biome of South Africa. South African Journal of Science $78,58-68$.

Gillson, L., Hoffman, M.T., 2007. Rangeland ecology in a changing world. Science 315, 53-54.

Hassan, R.M., Okbrich, B., 1999. Comparative analysis of the economic efficiency of water use by plantation forestry and irrigation agriculture in the Crocodile catchment. Agrekon 38, 566-575.

Heal, G., 2000. Valuing ecosystem services. Ecosystems 3 (1), 24-30.

Hein, L., van Koppen, K., de Groot, R.S., van Ierland, E.C., 2006. Spatial scales, stakeholders and the valuation of ecosystem services. Ecological Economics 57 (2), 209-228.

Herling, M.C., Cupido, C.F., O'Farrelldu, P.J., du Plessis, A., 2009. The financial costs of ecologically non-sustainable farming practices in a semi-arid system. Restoration Ecology 17 (6), 827-836.

Hewitson, B.C., Crane, R.G., 2006. Consensus between GCM climate change projections with empirical downscaling: precipitation downscaling over South Africa. International Journal of Climatology 26 (10), 1315-1337.

Hoffman, T., Ashwell, A., 2001. Nature Divided. Land Degredation in South Africa. University of Cape Town Press, Cape Town.

Hoffman, M.T., Rohde, R.F., 2007. From pastoralism to tourism: the historical impact of changing land use practices in Namaqualand. Journal of Arid Environments 70 (4), 641-658.

Hoffman, M.T., Allsopp, N., Rohde, R.F., 2007. Sustainable land use in Namaqualand, South Africa: key issues in an interdisciplinary debate. Journal of Arid Environments 70 (4), 561-569.

Illius, A.W., O'Connor, T.G., 1999. When is grazing a major determinant of rangeland condition and productivity?. In: People and Rangelands: Building the Future pp. 419-424. Proceedings of the 6th International Rangeland Congress.

James, I., Hoffman, M.T., Cowling, R.M., Roberts, R., Campbell, B.M., Boumans, R., Allsopp, N., 2005. Valuing Namaqualand's Natural Resources: The Costs and Benefits of Communal, Commercial and Conservation Land Use Practices in Namaqualand Incorporating Ecological, Economic and Social Values. Leslie Hill Institute for Plant Conservation and Terrestrial Ecology Research Unit, University of Cape Town, Cape Town.

James, I., Hoffman, T., Munro, A., O’Farrell, P., Smart, R., 2007. The value of flower tourism at the Namaqua National Park. South African Journal of Economic and Management Sciences 10 (4), 442-456.

Jelinski, D.E., Wu, J.G., 1996. The modifiable areal unit problem and implications for landscape ecology. Landscape Ecology 11 (3), 129-140.

Keay-Bright, J., Boardman, J., 2006. Changes in the distribution of degraded land over time in the central Karoo, South Africa. Catena 67 (1), 1-14.

Lange, G., Hassan, R., 2006. The Economics of Water Management in Southern Africa: An Environmental Accounting Approach. Edward Elgar, Cheltenham, UK.

Lange, G.-M., Mungatana, E., Hassan, R.M., 2007. Water accounting for the Orange River Basin: an economic perspective on managing a transboundary resource. Ecological Economics 61, 660-670.

Le Maitre, D., O'Farrell, P., 2008. Social-ecological resilience in a dry environment: people and water resources in the Little Karoo. In: Burns, M., Weaver, A. (Eds.) Advancing Sustainability Science in South Africa. Sun Press, Stellenbosch, South Africa.

Le Maitre, D.C., Milton, S.J., Jarmain, C., Colvin, C.A., Saayman, I., Vlok, J.H.J., 2007a Linking ecosystem services and water resources: landscape-scale hydrology of the Little Karoo. Frontiers in Ecology and the Environment 5 (5), 261-270.

Le Maitre, D.C., O’Farrell, P.J., Reyers, B., 2007b. Ecosystems services in South Africa: a research theme that can engage environmental, economic and social scientists in the development of sustainability science? South African Journal of Science 103 (9-10), 367-376.
Ludwig, D., 2000. Limitations of economic valuation of ecosystems. Ecosystems 3, $31-35$

MacKellar, N.C., Hewitson, B.C., Tadross, M.A., 2007. Namaqualand's climate: recent historical changes and future scenarios. Journal of Arid Environments 70 (4), 604-614.

Mittermeier, R.A., Gil, P.R., Pilgrim, J., 2005. Hotspots Revisited: Earth's Biologically Richest and Most Endangered Terrestrial Ecoregions. Conservation International, Washington D.C.

Moolman, C.E., Blignaut, J.N., Van Eyden, R., 2006. Modelling the marginal revenue of water in selected agricultural commodities: a panel data approach. Agrekon $45,78-88$.

Mucina, L., Rutherford, M.C., 2006. The Vegetation of South Africa, Lesotho and Swaziland. Strelitzia 19. South African National Biodiversity Institute, Pretoria.

Mucina, L., Jurgensle Roux, N., le Roux, A., Rutherford, M.C., 2006. Succulent Karoo biome. In: Mucina, L., Rutherford, M.C. (Eds.), The Vegetation of South Africa, Lesotho, and Swaziland. Strelitzia, Pretoria.

Naidoo, R., Iwamura, T., 2007. Global-scale mapping of economic benefits from agricultural lands: implications for conservation priorities. Biological Conservation $140,40-49$

Nelson, E., Mendoza, G., Regetz, J., Polasky, S., Tallis, H., Cameron, D.R., Chan, K.M.A. Daily, G.C., Goldstein, J., Kareiva, P.M., Lonsdorf, E., Naidoo, R., Ricketts, T.H., Shaw, M.R., 2009. Modeling multiple ecosystem services, biodiversity conservation, commodity production, and tradeoffs at landscape scales. Frontiers in Ecology and the Environment 7 (1), 4-11.

Nieuwoudt, W.L., Backeberg, G.R., Du Plessis, H.M., 2004. The value of water in the South African economy: some implications. Agrekon 43, 162-183.

Norgaard, R.B., Barnard, P., Lavelle, P., 2007. Assessing and restoring natural capital across scales: lessons from the millennium ecosystem assessment. In: Aronson, J., Milton, S.J., Blignaut, J.N. (Eds.), Restoring Natural Capital: Science, Business and Practice. Island Press, Washington DC, USA, pp. 36-43.

O'Farrell, P.J., Donaldson, J.S., Hoffman, M.T., 2007. The influence of ecosystem goods and services on livestock management practices on the Bokkeveld plateau, South Africa. Agriculture Ecosystems \& Environment 122 (3), 312-324.

O'Farrell, PJ., Reyers, B., Le Maitre, D.C., Milton, S.J., Egoh, B., Maherry, A., Colvin, C. Atkinson, D., De Lange, W., Blignaut, J., Cowling, R.M., 2010. Multi-functional landscapes in semi arid environments: implications for biodiversity and ecosystem services. Landscape Ecology 25 (8), 1231-1246.

Redford, K.H., Adams, W.M., 2009. Payment for ecosystem services and the challenge of saving nature. Conservation Biology 23 (4), 785-787.

Reyers, B., O’Farrell, P.J., Cowling, R.M., Egoh, B.N., Le Maitre, D.C., Vlok, J.H.J., 2009. Ecosystem services, land-cover change, and stakeholders: finding a sustainable foothold for a semiarid biodiversity hotspot. Ecology and Society 14 (1).

Reyers, B., Roux, D.J., Cowling, R.M., Ginsburg, A.E., Nel, J.L., O’ Farrell, P., 2010. Putting conservation plans to work: conservation planning as a transdisciplinary process. Conservation Biology. doi:10.1111/j.1523-1739.2010.01497.x.

Richardson, F.D., Hahn, B.D., Hoffman, M.T., 2007. Modelling the sustainability and productivity of pastoral systems in the communal areas of Namaqualand. Journal of Arid Environments 70 (4), 701-717.

Rouget, M., Cowling, R.M., Vlok, J., Thompson, M., Balmford, A., 2006. Getting the biodiversity intactness index right: the importance of habitat degradation data. Global Change Biology 12 (11), 2032-2036.

SKEP, 2003. SKEP: A 20 Year Strategy. The Botanical Society of South Africa, Cape Town.

SKEP, 2008. Succulent Karoo Ecosystem Programme Rapid Appraisal Report. A discussion paper in preparation for strategic planning 2009-2014. SANBI, Cape Town.

Safriel, U., Adeel, Z., Niemeijer, D., Puigdefabregas, J., White, R., Lal, R., Winslow, M., Ziedler, J., Prince, S., Archer, E., King, C., 2005. Dryland systems. In: Hassan, R. Scholes, R.J., Ash, N. (Eds.), Findings of the Conditions and Trends Working Group of the Millennium Ecosystem Assessment. Ecosystems and Human Wellbeing, Vol. 1. Island Press, Washington, D.C., USA, pp. 623-662.

Scholes, R.J., 1998. The South African 1:250 000 Maps of Areas of Homogeneous Grazing Potential. Division of Water, Environment and Forestry Technology, CSIR, Pretoria

Shackleton, C.M., Shackleton, S.E., 2006. Household wealth status and natural resource use in the Kat River valley, South Africa. Ecological Economics 57, 306-317.

Shackleton, C., Shackleton, S., Gambiza, J., Nel, E., Rowntree, K., Urquhart, P., 2008. Links between Ecosystem Services and Poverty Alleviation: Situation Analysis for Arid and Semi-arid Lands in Southern Africa. Ecosystem Services and Poverty Reduction Research Programme. DFID, NERC, ESRC, DFID, UK.

Simpson, R.D., 1998. Economic analysis and ecosystems: some concepts and issues. Ecological Applications 8, 342-349.

Smith, A.B., 1983. Prehistoric pastoralism in the Southwestern Cape, South-Africa. World Archaeology 15 (1), 79-89.

Statistics South Africa, 2002. Census of Agriculture Provincial Statistics 2002: Western, Northern and Eastern Cape Financial and Production Statistics. Statistics South Africa, Pretoria.

Statistics South Africa, 2007. A National Poverty Line for South Africa. Discussion Paper. Statistics South Africa, National Treasury, Pretoria. http://www.treasury. gov.za/publications/other/povertyline/TreasuryStatsSApovertylinediscussionpa per.pdf.

Sutton, P.C., Costanza, R., 2002. Global estimates of market and non-market values derived from nighttime satellite imagery, land cover, and ecosystem service valuation. Ecological Economics 41 (3), 509-527. 
TEEB, 2008. The Economics of Ecosystems and Biodiversity: An Interim Report. European Commission, Brussels. www.teebweb.org (accessed 01.09.09.).

Tallis, H., Polasky, S., 2009. Mapping and valuing ecosystem services as an approach for conservation and natural-resource management. Year in Ecology and Conservation Biology 1162, 265-283.

Thompson, M., Vlok, J.H.J., Rouget, M., Hoffman, M.T., Balmford, A., Cowling, R.M. 2009. Mapping grazing-induced degradation in a semi-arid environment: a rapid and cost effective approach for assessment and monitoring. Environmental Management 43 (4), 585-596.

Thornton, G., Feinstein, K., 2003. The Tourism Industry in the Western Cape is Growing. Get All the Statistics and Figures in our Western Cape Trends Card. Tourism, Hospitality \& Leisure Specialists South African member of Grant Thornton International. Sourced from. http://wwwwesgro.co.za/February2008.

Todd, S.W., Hoffman, M.T., 1999. A fence-line contrast reveals effects of heavy grazing on plant diversity and community composition in Namaqualand, South Africa. Plant Ecology 142 (1-2), 169-178.

Turner, R.K., Adger, W.N., Brouwer, R., 1998. Ecosystem services value, research needs, and policy relevance: a commentary. Ecological Economics 25 (1), 61-65.

Turner, R.K., Paavola, J., Cooper, P., Farber, S., Jessamy, V., Georgiou, S., 2003. Valuing nature: lessons learned and future research directions. Ecological Economics 46 (3), 493-510.

Turner, W.R., Brandon, K., Brooks, T.M., Costanza, R., da Fonseca, G.A.B., Portela, R., 2007. Global conservation of biodiversity and ecosystem services. Bioscience 57 (10), 868-873.

Turner, R.K., Morse-Jones, S., Fisher, B., 2010. 2010. Ecosystem valuation. A sequential decision support system and quality assessment issues. Annals of the New York Academy of Sciences 1185, 79-101.

Turpie, J.K., Joubert, A.R., 2004. The value of flower tourism on the Bokkeveld Plateau, a botanical hotspot. Development Southern Africa 21 (4), 645-662.
Turpie, J.K., Marais, C., Blignaut, J.N., 2008. The working for water programme: evolution of a payments for ecosystem services mechanism that addresses both poverty and ecosystem service delivery in South Africa. Ecological Economics 65 (4), 788-798.

United Nations, 2006. System of Environmental Economic Accounting for Water Sourced from. http://unstats.un.org/unsd/envaccounting/ceea/PImeetings/ Handbook_Voorburg.pdf February 2009.

Van Rooyen, M.W., Grobbelaar, N., Theron, G.K., van Rooyen, N., 1990. The ephemerals of Namaqualand: effects of photoperiod, temperature and moisture stress on development and flowering of three species. Journal of Arid Environments $19,15-29$.

van Wilgen, B.W., Le Maitre, D.C., Cowling, R.M., 1998. Ecosystem services, efficiency, sustainability and equity: South Africa's working for water programme. Trends in Ecology \& Evolution 13 (9), 378.

Van der Merwe, F.J., Smith, W.A., 1991. Dierevoeding. Animal Science Uitgewers (Pty) Ltd, Cape Town.

Walker, B., Pearson1, L., Harris, M., Maler, K.-G., Li, C.-Z., Biggs, R., Baynes, T., 2009 Incorporating resilience in the assessment of inclusive wealth: an example from South East Australia. Environmental and Resource Economics. doi:10.1007/ s10640-009-9311-7.

Wendland, K.J., Honzak, M., Portela, R., Vitale, B., Rubinoff, S., Randrianarisoa, J., 2009. Targeting and implementing payments for ecosystem services: opportunities for bundling biodiversity conservation with carbon and wate services in Madagascar. Ecological Economics. doi:10.1016/j.ecolecon. 2009.01.002.

Wilson, K.A., McBride, M.F., Bode, M., Possingham, H.P., 2006. Prioritizing global conservation efforts. Nature 440, 337-340.

Wunder, S., 2005. Payments for Environmental Services: Some Nuts and Bolts. CIFOR. Occasional Paper No. 42 